\title{
BEA MASUK IMPOR TINJAUAN HUKUM ISLAM DAN UU NOMOR 17 TAHUN 2006 TENTANG PERUBAHAN ATAS UU NOMOR 10 TAHUN 1995 TENTANG KEPABEANAN
}

\author{
Moch. Yusuf Bachtiar \\ Fakultas Syari'ah UIN Maulana Malik Ibrahim Malang \\ bachtiar156@yahoo.com
}

\begin{abstract}
Abstrak
Import duty is one kind of new charges and under the authority of the Directorate General of Customs and Excise and has a very large share of both the income and state revenues from the domestic industry protection against attacks from abroad industry. Basic Law of Import Duty is under Article 12 of Law no. 10, 1995 On Customs which then made changes as stipulated in Law no. 17 of 2006 on the Amendment Law. 10, 1995 On Customs. In Civilization and Islamic Khazanah itself besides Zakat, Kharaj and Jizya as a form of tax on the community there is also some kind of import duty that begins with a varied amount kaafir Harbi to levy 1/10, dhimmi 2/10, and Muslim 4/10. However occurred Pros and Cons imposition of import duty on Muslims. The focus of research is on the Import Duties Law Indonesia terms of Islamic law. This research aimed to find out whether the determination of levies import duties today in accordance with the policy of the caliphate. If the same is made the same and what is different if what makes it different. This research uses the research literature by using the approach of laws and concepts and approaches using content analysis. This study concluded that the determination of levies import duty on Indonesia is in accordance with the concept of 'usyr in Islamic law and that makes it different is the use religon Islamic caliphate state while using the Indonesian nation-state.

Bea masuk import merupakan salah satu jenis pungutan yang ada dan di bawah kewenangan Direktorat Jenderal bead an cukai dan mempunyai andil yang sangat besar, baik terhadap pemasukan pendapatan Negara maupun perlindungan terhadap industry negeri dari serangan industry dari luar negeri. Dasar hukum pungutan bea masuk impor diatur dalam pasal 12 UU No 10 tahun 1995 tentang kepabeanan yang kemudian dilakukan perubahan sebagaimana yang diatur dalam UU No 17 tahun 2006 tentang perubahan UU No 10 tahun 1995 tentang kepabeanan. Penelitian ini focus pada hukum bea masuk impor di Indonesia ditinjau dari segi hukum islam. Penelitian ini ditujukan untuk mengetahui apakah penetapan pungutan bea masuk import saat ini juga sesuai dengan kebijakan pada masa kekhalifahan, jika sama apa kesamaannya dan jika berbeda apa perbedaannya. Penelitian ini menggunakan jenis penelitian kepustakaan dengan menggunakan penggunaan Undang-undang dan pendekatan konsep dan menggunakan analisa konten.kesimpulannya adalah bahwa penetapan adanya pungutan bea masuk impor di Indonesia adalah sesuai dengan konsep 'usyr dalam hukum Islam menggunakan religion state, sedangkan Indonesia menggunakan natin state.
\end{abstract}

Kata kunci : Pengaturan, bea masuk, hukum Islam 
Bea Masuk impor merupakan salah satu jenis pungutan yang ada dibawah kewenangan Direktorat Jenderal Bea \& Cukai dan mempunyai andil yang sangat besar, baik terhadap pemasukan pendapatan negara maupun perlindungan terhadap industri dalam negeri dari serangan industri dari luar negeri. Dasar Hukum Pungutan Bea Masuk Impor diatur dalam Pasal 12 UU Nomor 10 Tahun 1995 Tentang Kepabeanan yang kemudian diubah dengan UU Nomor 17 Tahun 2006.

Peradaban dan Khazanah Islam mengatur, selain Zakat, Kharaj dan Jizyah sebagai bentuk pungutan terhadap masyarakat, juga ada semacam Bea Masuk Impor yang besarannya variatif, dimulai dengan orang kafir harbi dengan pungutan $1 / 10$, dzimmi $2 / 10$, dan muslim 4/10. Akan tetapi kemudian terjadi pro dan kontra pengenaan bea masuk impor terhadap orang muslim.

Fokus penelitian adalah Hukum Bea Masuk Impor di Indonesia ditinjau dari segi hukum Islam. Penelitan ini ditujukan untuk mengetahui apakah penetapan pungutan bea masuk impor saat ini juga sesuai dengan kebijakan pada masa kekhalifahan. Jika sama apa yang menjadikan sama dan jika berbeda apa yang menjadikannya berbeda.

Penelitian ini menggunakan jenis penelitian kepustakaan dengan menggunakan pendekatan UU dan pendekatan konsep serta menggunakan analisa konten.

Penelitian ini menghasilkan kesimpulan bahwa penetapan adanya pungutan bea masuk impor di indonesia adalah sesuai dengan konsep 'usyr dalam hukum Islam dan yang menjadikannya berbeda adalah pada masa kekhalifahan Islam, menggunakan religion state sedangkan Indonesia menggunakan nation-state.

\section{Bea Masuk Impor: Dasar Hukum, Sejarah,dan Praktiknya di Indonesia}

\section{Dasar Hukum}

Bea masuk impor atau yang juga dikenal sebagai tarif adalah sejenis pajak yang dikenakan atas barang-barang yang diimpor ${ }^{1}$. Sementara menurut UU Nomor 17 Tahun 2006 Tentang Perubahan UU Nomor 10 Tahun 1995 Tentang Kepabeanan Pasal 1 poin 15 mendefinisikan pungutan negara ber-dasarkan UU ini yang dikenakan terhadap barang yang diimpor.

Dasar hukum adanya Bea Masuk Impor adalah Pasal 12 ayat (1) UU Nomor 10 Tahun 1995 Tentang Kepabeanan dan UU Nomor 7 Tahun 1994 tentang Pengesahan Agreement Establishing the World Trade Organization (Persetujuan Pembentukan Organisasi Perdagangan Dunia). Adapun dalam UU Nomor 17 Tahun 2006 Tentang Perubahan UU Nomor 10 Tahun 1995, pasal ini tidak dirubah sama sekali. Hal ini berarti dalam melaksanakan pungutan bea masuk impor, yang menjadi dasar hukum adalah UU Nomor 10 Tahun 1995 Tentang Kepabeanan Pasal 12 ayat (1) dan bukan UU Nomor 17 Tahun 2006 Tentang Perubahan atas UU Nomor 10 Tahun 1995 Tentang Kepabeanan. Sedangkan pengecualian maupun perubahan atas besaran tarif mengikuti ketentuan yang lain, baik itu pasal dan ayat selain pasal 12 ayat (1) maupun atas keputusan dan peraturan dari kementerian keuangan yang membawahi Direktorat Jenderal Bea Dan Cukai.

\section{Sejarah Bea Masuk Impor}

Penerapan bea masuk impor atau tarif adalah suatu kebijakan yang sangat tua dan secara tradisional telah digunakan sebagai sumber pemasukan bagi negara sejak lama ${ }^{2}$. Di negara modern, Amerika Serikat sebelum menetapkan pajak pendapatan sebagai salah satu pemasukan negara, telah melaksanakan kebijakan bea masuk impor. Akan tetapi, tujuannya tidak hanya sebagai pemasukan negara saja, juga sebagai salah satu bentuk proteksi terhadap sektor-sektor tertentu dalam negeri dari tekanan persaingan dengan

\footnotetext{
${ }^{1}$ Paul R. Krugman dan Maurice Obstfeld, "Ekonomi Internasional Teori Dan Kebijakan", diterjemahkan Dr. Faisal Basri, International Economics (Cet. I, Jakarta: PT Indeks, 2004), 233.

${ }^{2}$ Paul R. Krugman, Ekonomi Internasional, 234.
} 
barang impor. Begitu pula di Inggris. Pada abad ke sembilan belas, Inggris menerapkan kebijakan bea masuk impor pada produk-produk pertanian sebagai upaya melindungi industri pertanian dalam negeri. Kebijakan ini terkenal dengan nama Corn Law. ${ }^{3}$

Di Indonesia, Bea masuk impor sudah ada sejak zaman kerajaan-kerajaan nusantara. Akan tetapi, bukti otentik akan adanya pungutan bea masuk tidak ada. Baru setelah VOC masuk dan mengusai perdagangan di nusantara, ada semacam regelling yang mengatur tentang pungutan bea masuk impor. Dulu petugas "pungutan" dikenal dengan nama "Tollenaar" yang secara harfiah diterjemahkan sebagai penjaga tapal batas negara atau pantai yang bertugas memungut "Tol" atau sejenis upeti terhadap barang-barang tertentu yang dibawa masuk atau keluar lewat suatu tapal batas.

Selain itu, ada juga istilah lain seperti "Mantriboom" dan "Opasboom" yang dikaitkan pengertiannya dengan tanda tapal batas untuk pemeriksaan barang yang masuk dan keluar dari pelabuhan. Boom bisa berarti pohon, blok, tiang dll. Pada masa pemerintahan Hindia Belanda, sifat "pungutan" itu baru resmi sejak VOC menerapkan "pungutan" secara nasional.

Pada masa Hindia Belanda, ada istilah douane untuk sebutan para petugas "pungutan" karena dipengaruhi oleh para pedagang dan pembeli dari Perancis. Namun pada masa VOC, pemerintah Hindia Belanda meresmikan nama Bea Cukai adalah De Dienst der Invoer en Uitboerrechten en Accijnzen (I.U \& A) yang artinya Jawatan Bea Impor dan Ekspor serta Cukai. Para petugas I.U \& A mempunyai tugas memungut InvoerRechten (Bea Impor/masuk), Uitvoererechten (bea ekspor/keluar), dan Accijnzen (excisel cukai). Tugas memungut bea, ekspor dan cukai inilah yang

${ }^{3}$ Paul R. Krugman, Ekonomi Internasional. memunculkan istilah Bea dan Cukai di Indonesia.

Pada jaman sebelum pengakuan oleh Belanda kepada Indonesia sebagaimana yang terjadi pada jaman penjajahan Jepang, tidak diketahui tentang perkembangan lembaga Bea Cukai. Catatan sejarah sangat kurang dan belum menemukan dokumen-dokumen pendukung tentang perkembangan lembaga ini. Pada masa itu, segala se-suatunya dilakukan secara darurat. Akhirnya, setelah Indonesia merdeka, Bea dan Cukai resmi dibentuk pada tanggal 1 Oktober 1945 dengan nama Pejabatan Bea dan Cukai, yang kemudian pada tahun 1948 diubah menjadi Jawatan Bea dan Cukai sampai dengan tahun 1965, dan pada tanggal 19 Desember 1948 Presiden Republik Indonesia, Soekarno memberi mandat untuk menyusun Organisasi Kementerian Keuangan. Struktur organisasinya terlihat sekali mengambil alih bentuk "Zaimubu" (Jaman Jepang) dengan berbagai modifikasi sesuai dengan kebutuhan saat itu. Pada tanggal 5 Juli 1959 pemerintah RIS (Republik Indonesia Serikat) memutuskan untuk memberlakukan kembali UUD 1945 dan struktur organisasi gaya lama (I.U \& A) dengan sedikit modifikasi masih tetap berlaku hingga $1960^{4}$.

\section{Praktik Bea Masuk Impor}

\section{Institusi}

Pengorganisasian dalam melaksanakan suatu kegiatan sangatlah penting. Hal itu dilaksanakan agar tujuan dari suatu kegiatan itu bisa tercapai. Begitupun juga dengan praktik impor dan ekspor, kegiatan ini dilaksanakan oleh Direktorat Jenderal Bea dan Cukai sesuai dengan amanat Pasal 74 ayat (1) UU Nomor 10 Tahun 1995 tentang Kepabeanan yang berbunyi :

"Dalam melaksanakan tugas berdasarkan UU ini dan peraturan perun-

\footnotetext{
${ }^{4} \mathrm{http} / /$ sejarah.kompasiana.com/2013/05/13/sejarah-beadan-cukai-di-indonesia-559578.html, diakses tanggal 19 Maret 2014
} 
dang-undangan lain yang pelak-sanaannya dibebankan kepada Direktorat Jenderal, Pejabat Bea dan Cukai untuk mengamankan hak-hak negara berwenang mengambil tindakan yang diperlukan terhadap barang”.

Direktorat Jenderal Bea dan Cukai Dengan demikian Institusi yang berwenang dalam bidang Kepabeanan adalah.

\section{Fungsi dan Tujuan Bea Masuk Impor}

Bea masuk impor selain ber-fungsi sebagai salah satu pemasukan pendapatan negara, juga bertujuan antara lain :

Proteksi terhadap industri dalam negeri, tujuan ini menjadi salah satu tujuan terpenting dalam mendasari adanya kebijakan bea masuk impor;

Pencegahan penyelundupan dari barang-barang impor illegal. Baik itu karena tidak adanya dokumen maupun karena barang tersebut memang tidak diperbolehkan masuk seperti narkoba dan lainnya;

Perlindungan yang bersifat sementara;

Efisiensi administrasi kepabeanan. ${ }^{5}$

\section{Jenis-Jenis Bea Masuk Impor}

Terdapat lima jenis pungutan impor menurut UU Nomor 17 Tahun 2006 tentang Kepabeanan, yaitu Bea Masuk (pasal 12 dan 13), Bea Masuk Anti Dumping (pasal 18 dan 19) Bea Masuk Imbalan (pasal 21 dan 22), Bea Masuk Tindakan Pengaman (pasal 23 A dan 23 B), dan Bea Masuk Pembalasan (pasal 23 C).

\section{Bea Masuk}

Sesuai pasal 12 UU Kepabeanan, barang impor dipungut Bea Masuk berdasarkan tarif setinggi-tingginya empat puluh persen dari nilai pabean untuk penghitungan Bea Masuk.

Dengan memperhatikan UU Nomor 7 Tahun 1994 tentang Pengesahan

\footnotetext{
${ }^{5}$ Marolop Tandjung, “Aspek Dan Prosedur Ekspor Impor", (Jakarta: Salemba Empat, 2010), 414.
}

Agreement Establishing the World Trade Organization (Persetujuan Pembentukan Organisasi Perdagangan Dunia), besarnya tarif maksimum ditetapkan setinggi-tingginya empat puluh persen termasuk Bea Masuk Tambahan (BMT) yang pada waktu diundangkannya UU Kepabeanan, masih dikenakan terhadap barang-barang ter-tentu. Namun, dengan tetap memperhatikan kemampuan daya saing industri dalam negeri, kebijaksanaan umum di bidang tarif harus senantiasa ditujukan untuk menurunkan tingkat tarif yang ada dengan tujuan :

negeri;

Melindungi konsumen dalam

Meningkatkan daya saing produk Indonesia di pasaran internasional; dan

Mengurangi hambatan dalam perdagangan internasional dalam rangka mendukung terciptanya perdagangan bebas.

Sesuai dengan Notifikasi Indonesia pada Persetujuan Umum Mengenai Tarif dan Perdagangan (GATT), dikecualikan ketentuan maksimum sebesar $40 \%$ tersebut diatas adalah :

Barang impor hasil pertanian tertentu, produk pertanian tertentu sebagaimana tercantum dalam Skedul XXIIndonesia, tarif Bea Masuknya diikut pada tingkat yang lebih tinggi dari empat puluh persen, dengan tujuan untuk menghapus penggunaan hambatan nontarif sehingga menjadi tarifikasi;

Barang impor termasuk dalam daftar eksklusif Skedul XXI-Indonesia pada Persetujuan Umum Mengenai tarif dan Perdagangan. Tujuannya adalah demi kepentingan nasional, produk tertentu yang termasuk dalam daftar ekslusif Skedul XXI-Indonesia, tarif Bea Masuknya tidak diikat pada tingkat tarif tertentu sehingga dikecualikan dari ketentuan pengenaan tarif maksimum 40 $\%$. Namun, dalam jangka waktu tertentu tarif atas produk tersebut akan diturunkan;

Barang impor sebagaimana dimaksud dalam Pasal 13 ayat (1) UU Kepabeanan sebagai berikut :

Barang impor yang dikenakan tarif Bea Masuk berdasarkan perjanjian 
atau kesepakatan internasional. Tarif Bea Masuk dikenakan berdasarkan perjanjian atau kesepakatan yang dilakukan Pemerintah Republik Indonesia dengan pemerintah negara lain atau beberapa negara lain, misalnya Bea Masuk berdasarkan Common Effective Preferential Tarif untuk Asean Free Trade Area (CEPT for AFTA);

Barang impor bawaan penumpang, awak sarana pengangkut, pelintas batas, atau barang kiriman melalui pos atau jasa titipan. Dalam rangka mempermudah dan mempercepat penyelesaian impor barang bawaan penumpang, awak sarana pengangkut, pelintas batas, dan barang kiriman melalui pos atau jasa titipan, dapat dikenakan Bea Masuk berdasarkan tarif yang berbeda, misalnya dengan pengenaan tarif rata-rata. Ketentuan ini perlu, mengingat barangbarang yang dibawa oleh para penumpang, awak sarana pengangkut, dan pelintas batas pada umumnya terdiri dari beberapa jenis;

Barang impor yang berasal dari negara yang memperlakukan barang ekspor Indonesia secara diskriminatif. Dalam hal barang ekspor Indonesia diperlakukan secara tidak wajar oleh suatu negara misalnya dengan pembatasan, larangan, atau pengenaan tambahan Bea Masuk, barang-barang dari negara yang bersangkutan dapat dikenakan tarif yang besarnya berbeda dan dapat melebihi $40 \%$.

Bea Masuk Anti-Dumping

Bea Masuk Anti-Dumping dikenakan terhadap barang impor dalam hal :

Harga ekspor dari barang tersebut lebih rendah dari nilai normalnya;impor barang tersebut :

Menyebabkan kerugian terhadap industri dalam negeri yang memproduksi barang sejenis dengan barang tersebut;

Mengecam terjadinya kerugian terhadap industri dalam negeri yang memproduksi barang sejenis dengan barang tersebut; dan
Menghalangi pengembangan industri barang sejenis didalam negeri.

Yang dimaksud dengan "harga ekspor" adalah harga yang sebenarnya dibayar atau akan dibayar untuk barang yang diekspor ke Daerah Pabean Indonesia. $^{6}$

Dalam hal diketahui adanya hubungan antara importir dan eksportir atau pihak ketiga, atau karena alasan tertentu harga ekspor diragukan kebenarannya, harga ekspor ditetapkan berdasarkan :

Harga dari barang impor dimaksud yang dijual kembali untuk pertama kali kepada pembeli yang bebas; atau

Harga yang wajar, dalam hal tidak terdapat penjualan kembali kepada pembeli yang bebas atau tidak dijual kembali dalam kondisi seperti pada waktu diimpor.

Yang dimaksud dengan "nilai normal" adalah harga yang sebenarnya dibayar atau akan dibayar untuk barang sejenis dalam perdagangan pada umumnya di pasar domestik negara pengekspor untuk tujuan konsumsi. Dalam hal tidak terdapat barang sejenis yang dijual di pasar domestik negara pengekspor atau volume penjualan di pasar domestik negara pengekspor relatif kecil sehingga tidak dapat digunakan sebagai pembanding, nilai normal ditetapkan berdasarkan:

Harga tinggi barang sejenis yang diekspor ke negara ketiga; atau

Harga yang dibentuk dari penjumlahan biaya produksi, biaya administrasi, biaya penjualan, dan laba yang wajar (constructedvalue).

Yang dimaksud dengan "barang sejenis" adalah barang yang identik atau sama dalam segala hal dengan barang impor dimaksud atau barang yang memiliki karakteristik fisik, teknik, atau kimiawi menyerupai barang impor dimaksud.

${ }^{6}$ Kinosta, UU Kepabeanan, 76. 
Bea Masuk Antidumping dikenakan terhadap barang impor yang memenuhi kriteria tersebut diatas setinggitingginya sebesar selisih antara nilai normal dengan harga ekspor dari barang tersebut dan merupakan tambahan dari Bea Masuk yang dipungut berdasarkan Pasal 12 ayat (1) UU Kepabeanan.

Bea Masuk Imbalan

Bea Masuk Imbalan dikenakan terhadap barang impor dalam hal :

Ditemukan adanya subsidi yang diberikan oleh negara pengekspor terhadap barang tersebut, dan impor barang tersebut:

Menyebabkan kerugian terhadap industri dalam negeri yang memproduksi barang sejenis dengan barang tersebut;

Mengancam terjadinya kerugian terhadap industri dalam negeri yang memproduksi barang sejenis dengan barang tersebut; atau

Menghalangi pengembangan industri barang sejenis didalam negeri. adalah :

Yang dimaksud dengan "subsidi"

Setiap bantuan keuangan yang diberikan oleh pemerintah atau badanbadan Pemerintah baik langsung maupun tidak langsung kepada perusahaan, industri, kelompok industri, atau eksportir; atau

Setiap bentuk dukungan terhadap pendapatan atau harga yang diberikan secara langsung atau tidak langsung untuk meningkatkan ekspor atau menurunkan impor dari atau ke negara yang bersangkutan.

Bea Masuk Imbalan adalah tambahan dari Bea Masuk yang dipungut berdasarkan pasal 12 ayat (1) UU Kepabeanan, dikenakan terhadap barang impor yang memenuhi kriteria tersebut diatas setinggi-tingginya sebesar selisih antara subsidi dengan :

Biaya permohonan, tanggungan atau pungutan lain yang dikeluarkan untuk memperoleh subsidi; dan/atau
Pungutan yang dikenakan pada saat ekspor untuk mengganti subsidi yang diberikan kepada barang ekspor tersebut. ${ }^{7}$

Bea Masuk Pengaman

Yang dimaksud dengan bea masuk tindakan pengaman (safeguard) yaitu bea masuk yang dipungut sebagai akibat tindakan yang diambil pemerintah untuk memulihkan kerugian serius dan/atau mencegah ancaman kerugian serius terhadap industri dalam negeri sebagai akibat lonjakan impor barang sejenis atau barang yang secara langsung merupakan saingan hasil industri dalam negeri dengan tujuan agar industri dalam negeri yang mengalami kerugian serius dan/atau ancaman kerugian serius tersebut dapat melakukan penye-suaian struktural. ${ }^{8}$

Yang dimaksud kerugian serius adalah kerugian nyata yang diderita oleh industri dalam negeri. Kerugian tersebut harus didasarkan pada fakta-fakta, bukan berdasarkan tuduhan, dugaan atau perkiraan. Dewasa ini bea masuk tindakan pengaman dikenakan terhadap impor table ware dari negara-negara tertentu. Dalam hal tindakan pengaman telah ditetapkan dalam bentuk kuota (pembatasan impor), maka bea masuk tindakan pengaman tidak harus dikenakan.

Bea masuk tindakan pengaman paling tinggi sebesar jumlah yang dibutuhkan untuk mengatasi kerugian serius atau mencegah ancaman kerugian serius terhadap industri didalam negeri. Bea masuk tindakan pengaman merupakan tambahan bea masuk yang dipungut berdasarkan pasal 12 ayat (1) UU Kepabeanan.

Bea Masuk Pembalasan

Bea masuk pembalasan dikenakan terhadap barang impor yang berasal dari negara yang memperlakukan barang ekspor secara diskrimatif, yaitu perlakuan tidak wajar misalnya pembatasan, larangan atau pengenaan tambahan bea masuk.

\footnotetext{
${ }^{7}$ Kinosta, UU Kepabeanan, 78
}

${ }^{8}$ Kinosta, UU Kepabeanan, 79 
Bea masuk pembalasan merupakan tambahan bea masuk yangdipungut berdasarkan pasal 12 ayat (1) UU Kepabeanan. ${ }^{9}$

\section{Bea Masuk Impor dalam Hukum Islam, Sejarah, dan Tinjauan Fiqh}

\section{Pengertian Syari'ah, Fiqh dan Hukum Islam}

Secara etimologi, syari'ah berarti jalan ke tempat mata air. Sedangkan secara terminologi adalah seperangkat norma Tuhan yang mengatur hubungan antara manusia dengan Tuhannya, manusia dengan sesamanya dalam kehidupan sosial dan juga mengatur antara manusia dengan lingkungan alam sekitarnya. ${ }^{10}$

Syari'ah juga berarti secara terminologis sebagai hukum-hukum yang tetap yang disyari'atkan oleh Allah SWT melalui dalil-dalil yang terdapat dalam alQuran dan al- Sunnah. Dengan demikian, pengertian dan cakupan syari'ah sangatlah luas dan tidak hanya mencakup tentang hukum-hukum yang harus dipatuhi, akan tetapi juga merangkum moral, etika dan keyakinan.

Sedangkan fiqh yang secara etimologi berarti pemahaman dan secara terminologi berarti hukum-hukum syara' yang berkaitan dengan perbuatan manusia yang bersifat praktis yang digali dari sumber-sumbernya yang terperinci. Dalam hal ini lebih kepada bagaimana hukumnya suatu pekerjaan itu, apakah boleh atau tidak, apakah transaksi ini sah atau batal, apakah makanan ini diperbolehkan atau tidak.

Sedangkan terminologi Hukum Islam sendiri tidak dikenal dalam dunia Islam pada masa dahulu. Istilah ini lebih kepada hasil terjemahan hukum Islam berbahasa Inggris. Dalam kosa kata bahasa Inggris, syari'at Islam diterjemahkan

\footnotetext{
${ }^{9}$ Kinosta, UU Kepabeanan, 79

${ }^{10}$ Zainuddin Ali, "Hukum Islam", (Cet I, Jakarta: Sinar Grafika, 2006), 3
}

menjadi Islamic Law, sedangkan fiqh diterjemahkan menjadi Islamic Jurisprudence. Dari kosa kata Inggris ter-sebut, maka muncullah istilah hukum Islam yang mana jika tidak dipahami dengan benar akan menimbulkan ke-rancuan dikarenakan adanya perbedaan yang sangat signifkan antara Fiqh dengan Syari'ah. Beberapa perbedaan tersebut antara lain :

Syari'ah diturunakan oleh Allah SWT, sedangkan fiqh adalah hasil daripada pemikiran ulama yang mana pemikiran tersebut bersifat relatif dan tidak absolut.

Syariah adalah satu dan fiqh itu beragam. Al-Quran hanya satu, akan tetapi penafsiran apa yang ada didalamnya itu beragam, tergantung penafsirnnya.

Syari'ah tidaklah berubah oleh waktu maupun lokasi, sedangkan fiqh berubah menyesuaikan kondisi dan lingkungan.

Syari'ah ruang lingkupnya lebih luas dan tidak hanya menyangkut urusan perbuatan nyata manusia, akan tetapi juga merngatur tentang keyakinan, etika dan moral. Keluasan syari'ah ini tidak dimiliki fiqh yang hanya mengatur perbuatan manusia saja. Dan itu yang biasa disebut dengan istilah hukum pada masa modern ini.

Oleh karena itu, maksud daripada hukum Islam sebagai maksud daripada terjemahan Islamic jurisprudence adalah fiqh Islam dan bukan syari' ah Islam. ${ }^{11}$

\section{Historitas Bea Masuk Impor dalam Islam}

Bea masuk Impor dalam Islam sering disebut sebagai Al-'Usyr ( - العشر (العشور). Secara etimologi berarti satu persepuluh (1/10) atau sepersepuluh. Sedangkan secara terminologis adalah pungutan sepersepuluh yang diambil dari komoditas orang-orang kafir yang memasuki negara muslim dari negara Harbi jika memang disyaratkan seperti itu.

\footnotetext{
${ }^{11}$ Zainuddin, Hukum Islam, 4
} 
Imam diperbolehkan untuk menambah, mengurangi maupun menghapus pungutan tersebut jika terdapat maslahah. ${ }^{12}$

Sebelum Islam datang, ada tradisi di kalangan suku-suku arab yang sudah membumi untuk memungut upeti atau retribusi terhadap para kafilah dagang yang melewati wilayah mereka sebagai imbalan atas perlindungan yang mereka berikan ketika kafilah-kafilah itu melintas di tanah mereka atau sebagai kompensasi ketika kafilah- kafilah itu melewati tanah mereka.

Kompensasi ini merupakan sejenis pajak yang bersifat memaksa dan juga menekan dengan jumlah nominal tertentu. Bahkan, pungutan tersebut telah menjadi salah satu sumber pemasukan bagi sukusuku tersebut. Jika ada yang tidak mau membayar pungutuan tersebut, maka ia akan dicegat, barang dagangannya dirampas, dirampok dan bahkan pengawalpengawal kafilah tersebut dibunuh. Dan hal itu terjadi, bahkan seperti yang dialami oleh kafilah milik penguasa persia Kisra Anusyahwan. Kisra Anusyahwan pernah mengirim satu rombongan kafilah yang mengangkut kayu untuk bahan baku panah pada salah seorang pejabatnya di Yaman. Seperti kafilah kerajaan pada umunya, kafilah ini juga mendapat kawalan yang ketat mulai dari Madain sampai ke Herat. Dari Herat kafilah ini mendapatkan pengawalan lagi sampai ke Yamamah. Ketika di Yamamah inilah kafilah milik kisra dipungut sejumlah upeti sebagai kompensasi atas keamanan kafilah mereka. $^{13}$

Tatkala Islam datang, tradisi pungutan ini pun tetap berlanjut dan tetap eksis seperti sedia kala. Hanya istilahnya saja yang berbeda, kalau pada zaman sebelum Islam dinamakan ju'alah sedangkan pada zaman Islam dinamakan 'Usyr. Yaitu pungutan bea masuk yang

\footnotetext{
${ }^{12}$ Ahmad Syarbasha, "Qomus Al-Iqtishod AlIslami",,(TTP:Dar Al-Jail, 1981), 294

13 Khalil Abdul Karim, "Al-Judzur al-Tarikhiya li alSyari'ah al-Islamiyah", (Cet I, Cairo: Sina Publishing, 1990), 59.
}

diambil atas komoditas dagang. 'Usyr ini berlaku baik bagi Ahl-Harb, AhlDzimmah maupun muslim sendiri yang melewati perbatasan wilayah Islam. Dan orang yang pertama kali memberlakukan 'Usyr adalah Khalifah 'Umar bin Khottob. ${ }^{14}$

\section{Bea Masuk Impor di Indonesia Tinjauan Hukum Islam}

Bea masuk impor dalam Islam banyak yang berpendapat diperbolehkan, dengan dasar pendapat Khalifah Umar Bin Al-Khottob seperti yang diriwayatkan oleh Imam Malik bin Anas.

$$
\begin{aligned}
& \text { 1. حدثي يهيى عن مالك عن بن شهاب عن سالم بن عبد الله عن }
\end{aligned}
$$

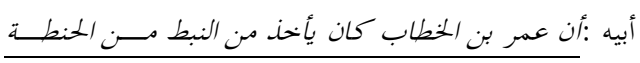

$$
\begin{aligned}
& \text { والزيت نصف العشر يريد بذلك أن يكثر الحمل إلى المدينسـة } \\
& \text { ويأخخ من القطنية العشر } 15 . \\
& \text { 2. حدثني عن مالك عن بن شهاب عن السائب بن يزيد أنسـه }
\end{aligned}
$$

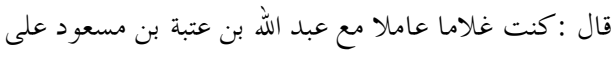

$$
\begin{aligned}
& \text { سوق المدينة في زمان عمر بن الخطاب فكنا نأخذ من النبط } \\
& \text { 3. } \\
& \text { يأحذ عمر بن الخطاب من النبط العشر فقال بن شهاب كان }
\end{aligned}
$$

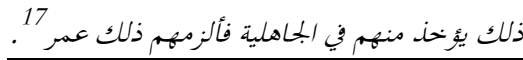

Dalam atsar tersebut, Imam Malik meriwayatkan bahwa Khalifah Umar Bin Al- Khottob telah memerintahkan kepada para pegawai pemerintahan untuk mengambil pungutan 'Usyr atau Bea masuk impor. Dalam atsar nomor 3 disebutkan bahwa ketika Ibn Syihab ditanya oleh Imam Malik Bin Anas "dengan dasar apa Umar menarik pungutan 'Usyr". Pada atsar yang pertama pun mengindikasikan bahwa umar selaku kholifah pada masa itu memerintahkan kepada pegawainya untuk mengambil bea masuk impor atau 'Usyr kepada orangorang Qibthy.

\footnotetext{
${ }^{14}$ Malik bin Anas, "Al-Muwatho"'.(Cet I, Abu Dhabi: Muassasah Zayid bin Sulthon, 2004), 400/2.

${ }_{15}$ Malik bin Anas, "Al-Muwatho", 400/2

${ }^{16}$ Malik bin Anas, "Al-Muwatho", 401/2.

${ }^{17}$ Malik bin Anas, "Al-Muwatho", 402/2
} 
Akan tetapi ada satu hadits yang diriwayatkan oleh Abu Daud dalam sunannya yang menyatakan bahwa 'Usyr tidak dikenakan pada orang Islam.

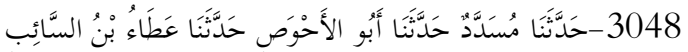

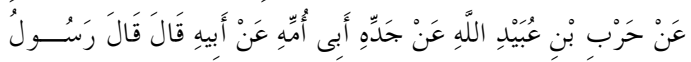

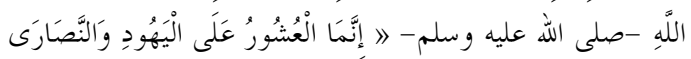

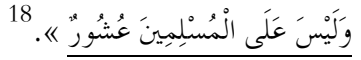

Dalam hadits ini secara eksplisit menyatakan bahwa 'Usyr hanya dikenakan pada orang yahudi dan nasrani dan tidak dikenakan pada orang Islam. Postulat ini menjadi bertentangan jika dibenturkan dengan atsar yang menyatakan bahwa 'Umar bin al- khottob yang memerintahkan kepada pegawainya untuk mengambil pungutan 'Usyr baik kepada Nasrani, Yahudi maupun Muslim sendiri.

Dikarenakan adanya pertentangan tersebut maka harus ada suatu cara agar dua sumber hukum dalam Islam tersebut tidak bertentangan atau dalam istilah ushul fiqh adalah jam 'u wa taufiq. Jika memang tidak bisa dikompromikan maka harus diunggulkan salah satunya, langkah terakhir jika memang tidak bisa dikompromikan maupun tidak bisa diunggulkan salah satunya. Maka langkah terakhir adalah tawaquf anhu atau berdiam diri dari masalah tersebut.

Oleh karena dua sumber hukum tersebut termasuk sumber hukum yang diakui oleh jumhur ulama'. Maka kami perlu meneliti kevalidan dan maksud dari pada sumber tersebut. Yang menjadi objek penelitain kami yang pertama adalah hadits yang diriwayatkan oleh Abu Daud sebagaimana dibawah ini :

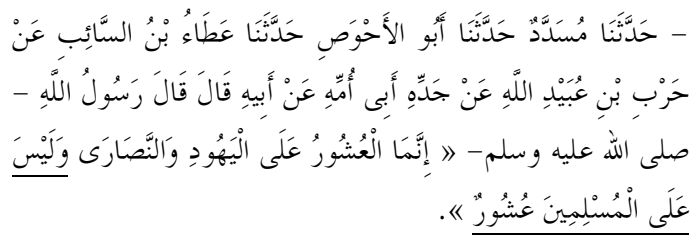

\footnotetext{
${ }^{18} \mathrm{Abu}$ Daud Sulayman bin Al-Asy'ats, "Sunan $A b i$
} Daud”, (Beyrut: Dar al-Kutub al-Ilmiyah, ttp), 135/3
Hadits tersebut diriwayatkan oleh Abu Daud dari Musadda dari Abu AlAkhwas dari Atho' Bin Saib dari Harb Bin Ubadillah dari kakeknya bapak ibunya dari bapaknya.

Jika dibuat silsilah sanad maka sebagai berikut :

Rasulullah SAW.

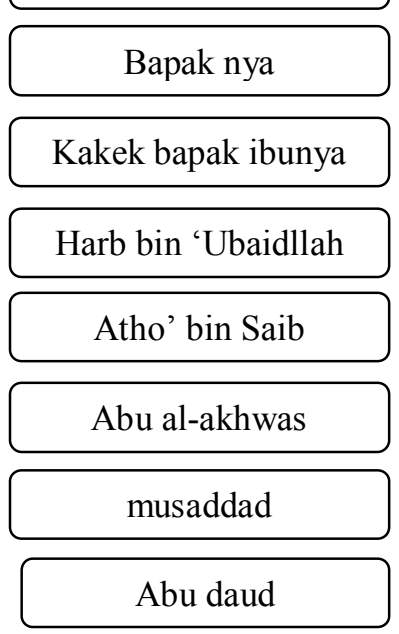

Dilihat dari diagram diatas, ada dua nama yang masih belum jelas yaitu kakek bapak ibunya Harb bin "Ubaidillah dan juga bapaknya kakek bapak ibunya Harb bin 'Ubaidillah. Dari sini kami mencoba untuk menulusuri siapa tokoh-tokoh rawi tersebut dan juga bagaimana status mereka dalam periwayatan hadits.

Pertama, Musaddad sebagai guru langsung dari Abu Daud. Nama lengkapnya adalah مسددبنمسر هدبنمسربلالبصريالاسديأبو الحسنالحافظ. Selain Abu Daud, haditsnya juga diriwayatkan oleh Al-Bukhori, Al-Tirmidzi dan Al-Nasaiy. Beliau meri-wayatkan hadits salah satunya dari Abu Al-Ahwash. Akan tetapi, dalam keterangan yang disampaikan oleh kitab Tadzhib alTadzhib tidak disebutkan siapa yang dimaksud dengan nama panggilan Abu alAhwash itu. Sedangkan dalam kitab Tadzhib Al-Tadzhib ada beberapa orang yang mempunyai nama panggilan Abu AlAhwash. 
Status beliau dalam periwayatan hadits menurut para ulama' jarh ta'dil diantaranya adalah tsiqqoh dan juga shoduq. Diantara yang berpendapat bahwa beliau tsiqqoh adalah al-Nasaiy dan Ja'far bin Abu 'Utsman. Sedangkan yang memberikan ta'dil bahwa beliau adalah seorang yang shoduq adalah Muhammad bin Hanun. Beliau wafat pada tahun 228 H. Sedangkan umur dan tahun kelahiran beliau tidak diketahui. ${ }^{19}$

Kedua, Abu al-Ahwash. Nama penggilan $\mathrm{Abu}$ al-Ahwash dalam periwayatan hadits ada beberapa orang yaitu, 'Amr Bin Raziq, Muhammad Bin Hayyan, Salam Bin Salim, 'Auf Bin Malik dan Ibn Harb. Setelah meneliti dari beberapa yang mempunyai kunyah (nama panggilan) Abu al-Ahwash yang mempunyai murid Musaddad Bin Masrahad dan mempunyai guru Atho' Bin Saib adalah Salam Bin Salim.

Nama lengkap beliau adalah سلامبنسليمالحنفيمو لا همأبو الأحو صالكوفيالحافظ

beliau mempunyai murid antara lain Musaddad, Ibn Abu Syaibah dan lainnya. Sedangkan guru beliau antara lain Atho' Bin Saib, Amar Bin Raziq yang juga mempunyai kunyah Abu al-Ahwash dan lainnya.

Status beliau sebagai perawi hadits dinilai oleh Yahya Bin Mu'in sebagai seorang tsiqqoh yang mutqon. Begitu juga pendapat al-Nasaiy dan Abd Al-Rahman Bin Abi Hatim yang sama-sama memberikan status sebagai orang yang tsiqqoh. Menurut al- Bukhori beliau wafat pada tahun yang sama ketika Hammad Bin Zaid dan Malik Bin Anas meninggal yaitu pada tahun $179 \mathrm{H}^{20}$

Ketiga, orang ketiga dalam periwayatan hadits yang menjadi obyek

19 Yusuf bin Al-Zakiy, Tadzhib al-Kamal, (Beyrut:Muassasah al - Risalah,1980), 443/27, Ahmad bin Ali Ibn Hajar al-Asqolani, Tadzhib al-Tadzhib, (Cet. I:Beyrut,Dar al-Fikr, 1984), 98/10.

20 Yusuf bin al-Zakiy, Tadzhib al-Kamal,282/12,; Ahmad bin Ali Ibn Hajar al-Asqolani, Tadzhib al- Tadzhib,248/4. penelitian ini Adalah Atho' Bin Saib. Nama lengkap beliau adalah عطاءبنالسائبينمالك yang mempunyai kunyah abu zaid al-tsaqofi al-Kufi. Diantara guruguru beliau adalah Harb bin abdullah alTsaqofi, Anas bin Malik, Thowus bin Kaysan dan lainnya. Sedangkan diantara murid- murid beliau adalah abu al-Ahwash Salam bin Salam, Amar bin Raziq Abu alAhwash dan lainnya.

Status beliau di kalangan ulama jarh wa ta'dil menurut Abu Hatim bahwa beliau dahulunya adalah orang yang shodiq, akan tetapi ketika sudah beranjak tua, terdapat ikhtilath ketika beliau meriwayatkan haditsnya. Menurut alNasaiy pun beliau adalah sosok yang tsiqqoh akan tetapi kemudian beliau berubah. Tahun lahir dan wafat beliau tidak diketahui. $^{21}$

Keempat, orang keempat dalam periwayatan hadits objek adalah Harb bin Abdullah. Nama lengkap beliau adalah . Beliau meriwayatkan hadits dari kakeknya. Sedangkan orang yang meriwayatkan hadits dari beliau adalah Atho' bin Saib, akan tetapi keterangan ini menimbulkan ikhtilaf. Status beliau menurut Ibn Mui'n adalah masyhur. Ibn Hibban pun mencantumkan namanya dalam kitab al-Tsiqqoh. Sedangkan alBukhori memberikan status kepada beliau untuk tidak diikuti. Akan tetapi Abu Daud meriwayatkan hadits yang sanadnya bersambung sampai dengan beliau hanya satu hadits saja yakni hadits yang menjadi objek penelitian ini. ${ }^{22}$

Kelima dan Keenam, orang kelima dan keenam adalah orang yang misterius karena حربينعَبَيداللهبنعُمَيَر الثقفي meriwayatkan hadits dari kakek bapak dari ibunya dan kemudian bapak dari kakek dari ibunya, sehingga siapa nama perowi hadist tersebut tidak diketahui. Hal ini

\footnotetext{
${ }^{21}$ Yusuf bin al-Zakiy, Tadzhib al-Kamal,86/20; Ahmad bin Ali Ibn Hajar al-Asqolani, Tadzhib alTadzhib, 183/7.

${ }^{22}$ Yusuf bin al-Zakiy, Tadzhib al-Kamal, 528/5,; Ahmad bin Ali Ibn Hajar al-Asqolani, Tadzhib alTadzhib, 198/2.
} 
dikarenakan dalam budaya arab yang dijadikan pedoman dalam pedoman penulisan nasab adalah asal dari pada bapak dan bukan dari pihak ibu. Kalaupun itu dari pihak bapak mungkin akan mudah ketahuan siapa se-benarnya yang dimaksud oleh حربينعيَيَ اللهبنعُمَير الثقفي dengan kalimat جَدِّهِ أبَى أَمِّهِ Kalimat tersebutpun mengandung khilaf karena dalam beberapa riwayat bukan أَبِى أُمِّهِ lakan tetapi أبيأمية

Jika dilihat dari penjelasan diatas terkait kualitas beberapa rowi. Maka kualitas hadits yang menjadi objek penelitian tidak bisa dikatakan sebagai hadits yang Shohih. Hal ini dikarenakan adanya syarat yang kurang dari standar keshohihan suatu hadits yaitu kedhabitan seorang rawi.

Untuk menguatkan pendapat peneliti, maka peneliti juga mengutarakan pendapat para ulama yang kompeten di bidang hadits seperti Syekh Nasiruddin alAlbani, Dr. Yusuf Qardhawi dan lainnya. dalam takhrijnya al-Albani menuturkan bahwa hadits

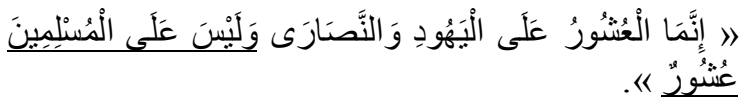

adalah hadits yang dloif. Hal ini dikarenakan dalam sanadnya ada Atho' bin Sai, tidak dketahuinya Harb bin Ubaidillah dan juga guru-gurunya. alBukhori sendiri juga memberikan statemen bahwa Harb bin Ubaidillah adalah orang yang tidak bisa diikuti. Demikian juga Dr. Yusuf Qardhawi sebagaimana dikutip oleh Khalil Abdul Karim bahwa hadits yang menyatakan tentang tidak adanya pungutan bea masuk impor adalah bukan hadits shoheh dan juga hadits hasan. Begitu juga yang dinyatakan oleh Dr. Kautsar Abdul Fattah al-Abaji, salah seorang dosen di fakultas perdagangan Universitas Kairo.

Dengan demikian, maka hadits diatas tidak dapat dijadikan hujjah dan postulat dalam penentuan hukum Islam. Karena yang bisa dijadikan hujjah dalam penetapan hukum Islam menurut jumhur ulama' adalah hadits shoheh. Jika hadits tersebut tidak dapat dijadikan dasar hukum. Maka secara otomatis larangan pungutan bea masuk impor terhadap umat Islam menjadi tidak berdasar dan tak ada landasan dalil yang mendukung dalam hal ini sehingga negara atau daulah boleh mengenakan pungutan bea masuk impor kepada muslim dan non muslim dengan besaran seperti yang telah ditentukan seperti yang diriwayatkan oleh yang menerangkan bahwa Umar bin Khottob selaku Khalifah pada waktu itu melakukan pungutan bea masuk impor kepada Muslim, Kafir Dzimmi dan juga Kafir Harbi.

Ketika dasar hukum dari pungutan bea masuk impor telah jelas dan juga bea masuk impor sendiri telah diperbolehkan kepada khayalak umum baik itu kepada Muslim, Nasrani dan Yahudi. Baik itu berstatus Kafir Dzimmi maupun Harbi, maka jelas bahwa hukum bea masuk impor yang dilaksanakan oleh pemerintah Indonesia yang mana dalam melakukan pungutan ini adalah Direktorat Jenderal Bea Dan Cukai dengan dasar UU Nomor 17 Tahun 2006 Tentang Perubahan UU Nomor 10 Tahun 1995 Tentang Kepabeanan Pasal 1 angka 10.

Jika dalam UU Nomor 17 Tahun 2006 Tentang Perubahan UU Nomor 10 Tahun 1995 Tentang Kepabeanan ada berbagai jenis bea masuk impor. Maka 'Usyr hanya mengenakan satu jenis bea masuk impor saja yang dalam UU Nomor 10 Tahun 1995 Tentang Kepabeanan yaitu Bea Masuk. Adapun jenis-jenis bea masuk impor yang lain seperti Bea Masuk Anti Dumping, Bea Masuk Pembalasan, Bea Masuk Imbalan adalah jenis-jenis bea masuk yang berkembang sesuai dengan perkembangan zaman dan perdagangan dunia. Dalam hal ini peneliti berpendapat bahwa dasar dari semua jenis bea masuk impor adalah bea masuk yang dalam litelatur fiqh klasik adalah 'Usyr sehingga hukumnya sama dengan Bea Masuk. 


\section{Simpulan}

Setelah mempelajari dan menganalisi UU Nomor 17 Tahun 2006 Tentang Perubahan UU Nomor 10 Tahun 1995 Tentang Kepabeanan dan juga Bea Masuk Impor dalam Islam yaitu 'Usyr dengan memperhatikan sumber-sumber hukumnya maka, kami mempunyai kesimpulan sebagai berikut :

Bea Masuk Impor di Indonesia sebagai mana yang diatur dalam UU Nomor 17 Tahun 2006 Tentang Perubahan UU Nomor 10 Tahun 1995 Tentang Kepabeanan dengan 'Usyr atau Bea Masuk Impor dalam Islam adalah salah satu bentuk yang sama. Yaitu pungutan terhadap orang yang berdagang di wilayah mereka dengan prosentase yang berbeda-beda sesuai dengan kondisi zaman.. Sedangkan pada zaman modern yang dijadikan acuan adalah tarif spesifik dan tarif add valorem.

Status hadits yang menyatakan bahwa tidak ada pungutan bea masuk impor kepada umat Islam adalah hadits yang dhoif sehingga tidak bisa dijadikan dasar hukum. Mayoritas ulama mem-perbolehkan pungutan bea masuk impor yang dilakukan oleh pemerintah seperti Malik bin Anas, Abu Yusuf dan al-Syafi' i.

\section{Saran}

Perkembangan jenis dan pungutan bea masuk impor haruslah sesuai dengan tujuan pembangunan dan perlindungan bagi rakyat. Sehingga bisa tercipta perdagangan yang sehat dan juga perlindungan usaha dan perdagangan dalam negeri.

Penelitian-penelitian yang bersifat kebijakan keuangan publik terutama berkaitan dengan hukum Islam harusnya dikembangkan lebih lanjut. Dengan adanya penelitian-penelitian tersebut tidak di-temukan aspek-aspek penunjang Raison $d$ etre nya kebijakan keuangan publik baik da-lam hukum positif maupun hukum Islam dan bahkan intregasi antara keduanya.

\section{DAFTAR PUSTAKA}

\section{Buku :}

Ali, Zainuddin, 2006, “Hukum Islam”, Cet I, Jakarta: Sinar Grafika

Ibn Hajar al-Asqolani, Ahmad bin Ali, 1984, “ Tadzhib al-Tadzhib”, Cet. I, Beyrut, Dar al-Fikr

Karim, Khalil Abdul, 1990, "Al-Judzur alTarikhiya li al-Syari'ah al-Islamiyah", Cet I, Cairo: Sina Publishing

Krugman, Paul R. dan Maurice Obstfeld, 2004, "Ekonomi internasional teori dan kebijakan", diterjemahkan Dr. Faisal Basri, International Economics, Cet. I, Jakarta: PT. Indeks.

Malik bin Anas, 2004, "Al-Muwatho"'.Cet I, Abu Dhabi: Muassasah Zayid bin Sulthon Sulayman bin Al-Asy'ats, Abu Daud, "Sunan Abi Daud", Beyrut: Dar al-Kutub al- Ilmiyah

Syarbasha, Ahmad,1981,"Qomus Al-Iqtishod Al-Islami", ttp: Dar Al-Jail

Tandjung Marolop, 2010, “Aspek dan prosedur ekspor impor", Jakarta : Salemba Empat

Yusuf bin al-Zakiy, 1980, Tadzhib Al-Kamal, Beyrut: Muassasah al-Risalah

\section{Makalah pelatihan :}

Kinosta Illatude, "Undang-Undang Kepabeanan", Modul, Disampaikan pada diklat subtantif spesialisasi Oktober 2007 Jakarta; Pusdiklat Bea \& Cukai.

\section{Web :}

http://sejarah.kompasiana.com/2013/05/13/seja rah-bea-dan-cukai-di-indonesia559578.html, diakses tanggal 19 Maret 2014 